\title{
A KÖZÉPKORI NORVÉG FATEMPLOMOK: ÉPITTETT ÖRÖKSÉG ÉS AZ EMLÉKEZET HELYEI
}

\author{
SziLÁgyi Kata ${ }^{1}$ - Anette SAND-Eriksen ${ }^{2}$ \\ Magyar Régészet 10. évf. (2021), 1. szám, pp. 30-40. https://doi.org/10.36245/mr.2021.1.5
}

A cikk a középpontjában a norvégiai középkori fatemplomok, más néven dongatemplomok állnak. A donga szó (jelentése oszlop, rúd) az épületre jellemzö oszlop- és gerendaszerkezetre utal, amely egyedi épitészeti megoldást képvisel. A fából készült keresztény épületek magasan fejlett hagyományát testesítik meg ezek a templomok, amelyek a középkorban (1050-1500) a mai Norvégia területén voltak a legelterjedtebbek, számukat hozzávetölegesen ezer körülire lehet becsülni. Valószínüleg más területeken is legalább ennyire elterjedtek voltak (pl. mai Németország és Oroszország területén), csak nem maradtak meg ilyen nagy számban a korai idöszakból. Mindamellett, hogy a dongatemplomok száma drámaian lecsökkent, összesen 28 közülük ma is épségben látható. A cikk a dongatemplomok egyedi és pótolhatatlan faépitészetének ismeretét kívánja bőviteni. Bár a fatemplomokat hagyományosan Skandinávia egyik jellegzetességének tekintjük, ugyanakkor más kultúrák és országok épitészeti hatásait is elegyitik és hordozzák. A fatemplomok örökségi és emlékezeti szerepe, valamint a különbözö épitészeti és vallási elemek keveredésének témaköre érdekes összehasonlitást, esettanulmányt jelent a Kárpát-medence nézöpontjából. Erdély és különösen a Máramaros vidéke híres fatemplomairól és a gazdag faragott és festett ikonosztázokról.

Kulcsszavak: Észak-Európa, Norvégia, középkor, dongatemplom, fatemplom, faépítészet, északi stílus, kulturális memória, kulturális örökség

\section{MIK A DONGATEMPLOMOK ÉS MITÖL KÜLÖNLEGESEK?}

A középkorban hatalmas kő- vagy téglatemplomok épültek Európa-szerte. Norvégiában is hasonló építéstechnika fejlődött ki ugyanezen időszakban, egy nagy különbség volt azonban: a fó építőanyag. Míg Európa hatalmas részén a kőből és téglából készült falszerkezetet részesítették előnyben, addig Norvégiában fából készült a falazat, hiszen a fa mint építőanyag bőségesen rendelkezésre állt. Ennek eredményeként egyedi faépítmények, az úgynevezett donga- vagy oszloptemplomok (norvég nyelven: stavkirke) váltak a domináns vallási épülettípussá a középkor folyamán (1050-1500) (1. kép). Kárpát-medencei vonatkozásban ez kiváltképpen érdekes és releváns kitekintést és összehasonlítást jelent, hiszen a Norvég és a Magyar Királyság területén a kereszténység felvétele egy időben és sok tekintetben hasonló módon történt. A régi északi hitrendszer, akárcsak a pogány magyar hitvilág, folyamatosan alakult át és épült részben be a politikai, hatalmi szempontokból is elfogadott és egyértelmüen támogatott keresztény vallásba (BEREND et al. 2007, 319-320). Számos adat utal arra, hogy fatemplomok nagy számban épültek a kereszténység felvétele után szinte minden területen, így Magyarországon is, ám ezekből semmiféle

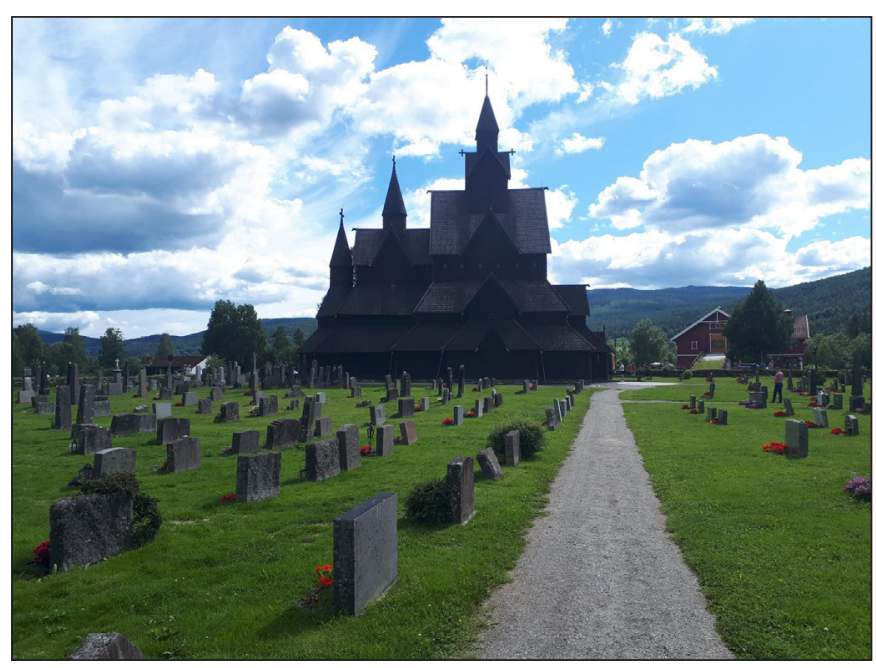

1. kép. A heddali dongatemplom Notoddenben (Telemark, Norvégia) (fotó: Szilágyi Kata)

\footnotetext{
University of Oslo, Faculty of Humanities, Department of Archaeology, Conservation and History, Oslo, Norway. E-mail: szil.szvetlana@gmail.com

2 University of Oslo, Museum of Cultural History, Oslo, Norway. E-mail: anette.sand-eriksen@khm.uio.no
} 
álló emlék nem maradt meg. Ezért is érdekes kérdés, hogy milyen nagyságú és jellegű fatemplomok épülhettek ebben a korai időszakban.

A fatemplomok oszlopokból (ónorvég nyelven: stafr, modern norvég nyelven: stav) álló falszerkezettel - magyarosan donga szerkezettel - rendelkeztek; ezek olyannyira jellegzetes elemei az épületeknek, hogy a középkori templomtípus is erről kapta a nevét. Ebben a keretben a függőlegesen elhelyezkedő oszlopok (másszóval rudak, pillérek) a vízszintesen fekvő talpfákon vagy (rönk)küszöbön állnak és tartják a tető vízszintes teherhordó oszlopait. Ez az építészeti módszer lehetővé teszi, hogy az elemek között tágas hely maradjon, így alakítva ki az épület nagy, nyitott terét, jellegzetes függőleges síkját és karakterisztikus megjelenését. Ez a módszer és építészeti megjelenítés éppen az ellenkezője a középkori Norvégiában szintén elterjedt, vízszintes szerkezetü rönkházaknak vagy borona házaknak.

Megközelítőleg 750 és 1300 közé becsülhető az egykoron létezett dongatemplomok száma Norvégiában (JENSENIUS 2000). Arányuk meglehetősen magas, tekintetbe véve, hogy 271 kőtemplom állhatott ugyanebben az időszakban. A nagy különbség egyrészt a bőségesen rendelkezésre álló faanyaggal magyarázható, de egyúttal a régi norvég törvények közvetlen eredményének is tekinthető, ugyanis ezek a dongatemplomokat határozták meg és szabályozták, mint szokásos templomépítészeti stílust (HAUGLID 1970; ANKER 1997, 2005). Norvégia legrégebbi írott törvényei és az Ónorvég Homíliás Könyv (Gammelnorsk homiliebok, szentírás magyarázó beszéd, 2. kép) szerint az egyház felszentelése mindaddig érvényes volt, amíg a négy sarokoszlop állt (BAMPI et al. 2018). A Homíliás Könyvben az egyik szentbeszédet „dongatemplom prédikációnak" is nevezik. Ez a szöveg az épületelemek teológiai értelmezésének is tekinthető (meghatározza a terminológiát és magyarázatot kínál a technika forrására), amelyet az 1100 körüli időszakra lehet keltezni (HoFtun 2008).

Bár a hagyományos faépület skandináv jellegzetesség, az építészeti hagyomány és az építkezési módszer Skandinávián kívül is elterjedt, és más kultúrákból és országokból származó hatások is jelen voltak Norvégiában. Az urnesi dongatemplom tökéletes példája annak, hogyan keverednek a kelta müvészet, a viking hagyomány és a román stílus különféle müvészeti elemei. Ezek az épületek egyediek és pótolhatatlanok, így az urnesi dongatemplom 1979-ben felkerült az UNESCO Világörökségi listájára is; ennek jelentőségét fontos kiemelni, hiszen ekkor még csak egyes müemlékeket vettek fel a listára. Ez fontos lépés volt ennek a különleges és kulcsfontosságú építészeti hagyománynak a müemléki védelme és megörzése érdekében, számuk ugyanis drámaian lecsökkent, napjainkban mindösszesen 28 épület látható épségben (CHRISTIE 1981, 139-203; JENSENIUs 2000, 7-10) (1. táblázat; 3. kép). A norvég példához hasonlóan a máramarosi fatemplomok is az UNESCO Világörökségi helyszínei közé tartoznak és 1999 óta müemléki védettség alá esnek. Továbbá a Kárpátok régiójában a szlovákiai és a kis-lengyelországi fatemplomok - amelyek időben későbbiek, mint a norvégiai emlékek jelentős része - is a Világörökségi listán szerepelnek.

\begin{tabular}{|c|l|l|l|l|}
\hline Lelöhely-azonosító & Név & Község/Járás & Megye & Időszak \\
\hline 1 & Borgund & Lærdal & Sogn og Fjordane & 12. század eleje \\
\hline 2 & Eidsborg & Tokke & Telemark & 13. század \\
\hline 3 & Flesberg & Flesberg & Buskerud & kb. 1150-1200 \\
\hline 4 & Garmo & Lom/Lillehammer & Oppland & kb. 1150-1200 \\
\hline 5 & Gol & Gol & Buskerud & 13. század eleje \\
\hline 6 & Grip & Kristiansund & Møre og Romsdal & 14-15. század \\
\hline 7 & Haltdalen & Holtålen & Sør-Trøndelag & 12. század vége \\
\hline 8 & Hedalen & Sør-Aurdal & Oppland & 12. század vége \\
\hline 9 & Heddal & Notodden & Telemark & 13. század eleje \\
\hline 10 & Hegge & Øystre Slidre & Oppland & 13. század eleje \\
\hline 11 & Hopperstad & Vik & Sogn og Fjordane & 12. század eleje \\
\hline 12 & Høre & Oppland & Oppland & 12. század vége \\
\hline 13 & Høyjord & Andebu & Vestfold & 12. század vége \\
\hline 14 & Kaupanger & Sogndal & Sogn og Fjordane & 12. század vége \\
\hline
\end{tabular}


Szilágyi Kata-Anette Sand-Eriksen • A középkori norvég fatemplomok: épitett örökség és az emlékezet helyei

\begin{tabular}{|l|l|l|l|l|}
\hline 15 & Kvernes & Averøy & Møre og Romsdal & 14. század vége* \\
\hline 16 & Lom & Lom & Oppland & 12. század vége \\
\hline 17 & Lomen & Vestre Slidre & Oppland & 12. század vége \\
\hline 18 & Nore & Nore og Uvdal & Buskerud & 12. század vége \\
\hline 19 & Øye & Vang & Oppland & 12. század vége \\
\hline 20 & Reinli & Sør-Aurdal & Oppland & 12. század vége \\
\hline 21 & Ringebu & Ringebu & Oppland & 12-13. század \\
\hline 22 & Rødven & Rauma & Møre og Romsdal & 12-13. század \\
\hline 23 & Røldal & Odda & Hordaland & 12-13. század \\
\hline 24 & Rollag & Rollag & Buskerud & 12. század vége \\
\hline 25 & Torpo & All & Buskerud & 12. század vége \\
\hline 26 & Undredal & Aurland & Sogn og Fjordane & 12. század vége \\
\hline 27 & Urnes & Luster & Sogn og Fjordane & 12. század eleje \\
\hline 28 & Uvdal & Nore og Uvdal & Buskerud & 12. század vége \\
\hline
\end{tabular}

1. táblázat. Áttekintő táblázat az épségben megmaradt norvég dongatemplomok legfontosabb adataival (az adatok forrása: TSCHUDI-MADSEN 2019; STAVKYRKJEEIGARFORUM 2020; JENSENIUS 2017; WIKIPEDIA 2020). *az új datálás alapján 1631-1633

\section{TÖRTÉNETI HÁTTÉR}

A dongatemplomok a 11. század elején jelentek meg Skandináviában, szinte egyidőben azzal, amikor - több évszázados átmeneti időszakot követően - a kereszténység meghonosodott és államvallássá vált Norvégiában. A mai Anglia és Németország területéről érkezett keresztény misszióknak nagy jelentőséget tulajdoníthatunk, Ansgar (796-865 Hamburg-Bréma érseke) különösen fontos szerepet játszott ebben, majd öt követték a norvég királyok I. Håkon (920-961), I. Olav (963-1000) és a később szentté avatott II. Olav (995-1030) (AHRENS 1982, 37-40; ANker 1997, 202-204) (2. kép). Csaknem két évszázaddal a kereszténység terjedésének kezdetét követően is épültek dongatemplomok, de a misszionáriusok nem nézték jó szemmel a szinkretizmust, mivel a régi északi vallás számos eleme (pl. sárkányfejek, különleges lények ábrázolásai, régi északi szimbólumok faragványai stb.) felbukkan az épületeken. A régi északi és az új keresztény vallás kétszáz évig létezett egymás mellett, ezeknek keveredése és összeolvadása figyelhetö meg a templomok díszítésében is. Az eredeti skandináv hiedelemvilág elemei beépültek: a szimbólumok jelentős részét átformálták, az elbeszéléseket lefordították és újraértelmezték, így ezek a keresztény vallás részévé tudtak válni.

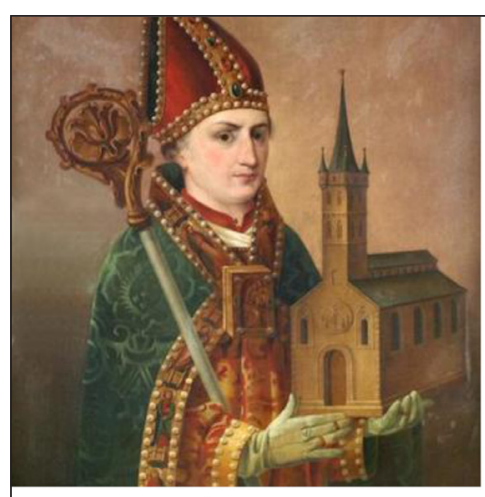

Ansgar

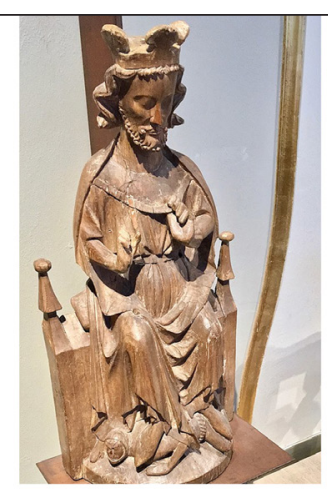

II. Olav

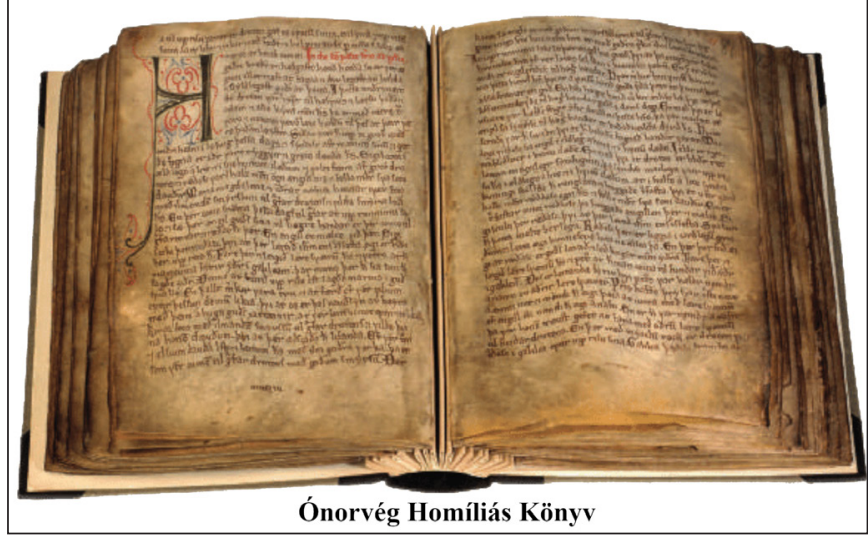

2. kép. Ansgar ábrázolása a St. Trinitatis templomban (Hamburg, 1457), II. Olav faragott szobra (Kulturhistorisk Museum, Oslo, 1260-1280), és az Ónorvég Homíliás Könyv (1200 körül) (a képek forrásai: Wikimedia Commons; BAMPI et al. 2018, 55)

A dongatemplomok különösen gyakori épületeknek tekinthetők az alacsony lélekszámú településeken, így főként a völgyek magasabb területein és erdőkben fordulnak elő, valamint szigeteken és a fjordok partszakaszai mentén. Különösen 1600 és 1700 között számos fatemplomot átalakítottak vagy más technikával szerkezetileg újjáépítettek. Ennek tökéletes 


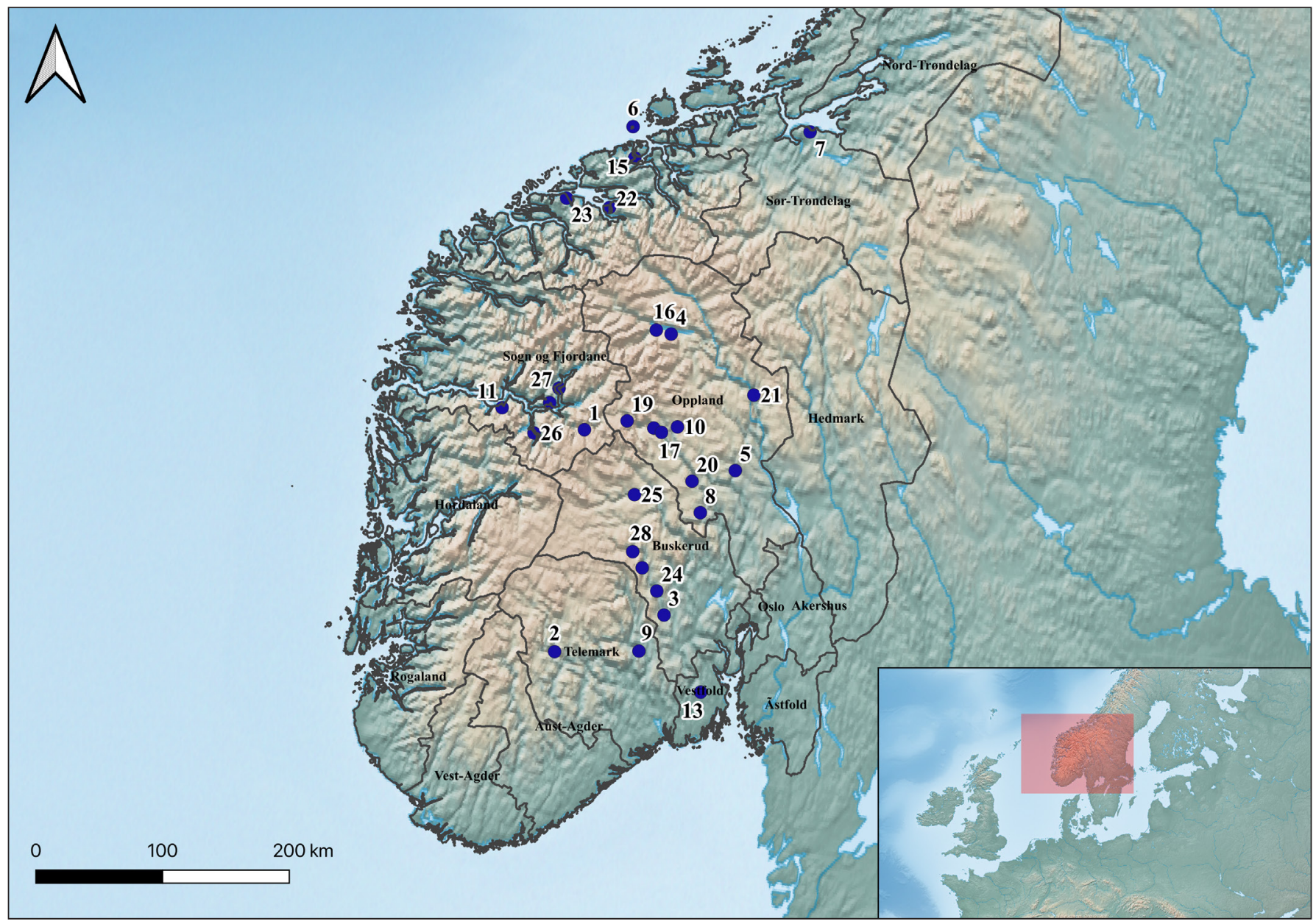

3. kép. Az épségben megmaradt dongatemplomok elhelyezkedése Norvégiában (térkép: Szilágyi Kata)

példájaként a flesbergi templomot lehet megemlíteni, amit részint vízszintes rönktechnikával formáltak át keresztalaprajzú épületté 1735-ben. A legtöbb fatemplom átalakításának, és különösen elbontásának egyik oka lehetett, hogy a régi templomok nem voltak elég nagyok az egyre növekvő létszámú hitközösségeknek; a másik indok vélhetően számos épület rossz állapota volt. Az emberi beavatkozások mellett számos templom természeti katasztrófák martalékává vált (pl. tűz, vihar, lavina és sziklaomlás). 1650ben az ismert dongatemplomok száma 270 körülire becsülhető, ebböl 136 az ezt követö évszázadban teljesen eltünt. 1800-ra csupán 95 ilyen templom maradt Norvégiában, és ez a szám 1885-re 32-re csökkent (ANKER 1997, 15). Ez utóbbi időszakban azonban a templomok egyedi építészetét újra felfedezték. A heddali volt az első, tudományos igénynyel ismertetett dongatemplom, amelyet Johannes Flintoe publikált (1834). Flintoe 1819-re keltezett rajza egyben az első ismert dongatemplom építészeti ábrázolás (4. kép). A 19. században folyamatosan nőtt az érdeklődés a dongatemplomok iránt, amelynek egyik csúcspontja volt Lorentz Dietrichson (1834-1917, norvég költő, művészetés irodalomtörténész) 1892-ben megjelent alapvető publikációja, De norske stavkirker (A norvég fatemplomok) címmel (ANKER 1997, 184-185).

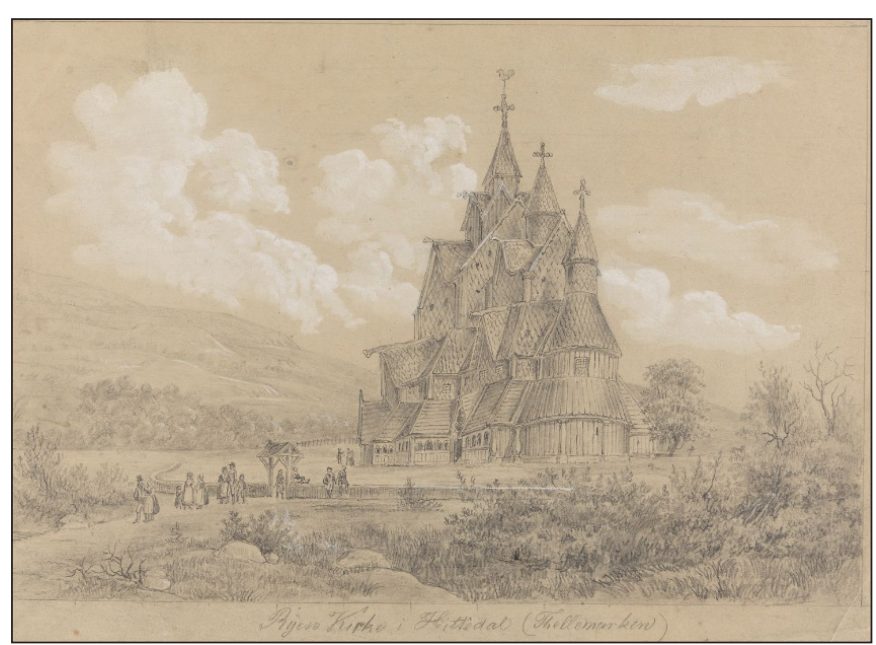

4. kép. Johannes Flintoe rajza a heddali dongatemplomról. Ceruzarajz papiron, 1848 (forrás: Nasjonalmuseet Oslo, https://nasjonalmuseet.no/samlingen/objekt NG.K_H.B.06314) 
Szilágyi Kata-Anette Sand-Eriksen • A középkori norvég fatemplomok: épített örökség és az emlékezet helyei

\section{A DONGATEMPLOMOK SZERKEZETI FELÉPÍTÉSE}

A dongatemplomok mindig négyzet alakúak és szilárd favázzal rendelkeznek, amit kőalapozásra építettek, föleg a vízkárok megakadályozásának érdekében. A dongaszerkezetet függőleges oszlopok (rudak) alkotják, amelyek egyben a teljes tetőszerkezetet is képezik. A legegyszerübb és valószínüleg a legrégebbi formának az egycsarnokos templomot tarthatjuk (ANKER 1997; 2005). Itt az oszlopok a falszerkezetben helyezkednek el, így biztosítva elegendő helyet a templom középső részének. Ez a szerkezettípus egyetlen hajóval rendelkezik, az oszlopok csak a falak külső sarkaiban találhatók meg. A falakat függőleges deszkákból alakították ki, amelyeket a keret vízszintes gerendájának vájatába (a horonyba) illesztettek be - a magyar népi építészetben ezt zsilipfalnak nevezzük. A bonyolultabb szerkezetü templomokban egy ún. galéria (norvégul: svalgang) is épült körben a fal külső oldala mentén, mintegy hagyma-

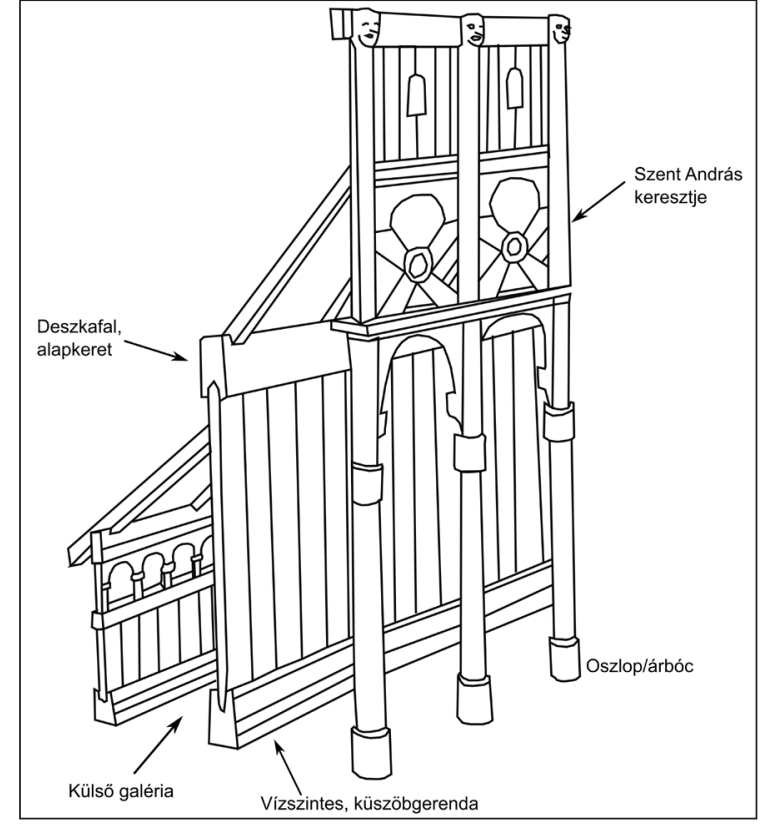

5. kép. A dongatemplom szerkezetének sematikus vázlata (rajz: Szilágyi Kata)

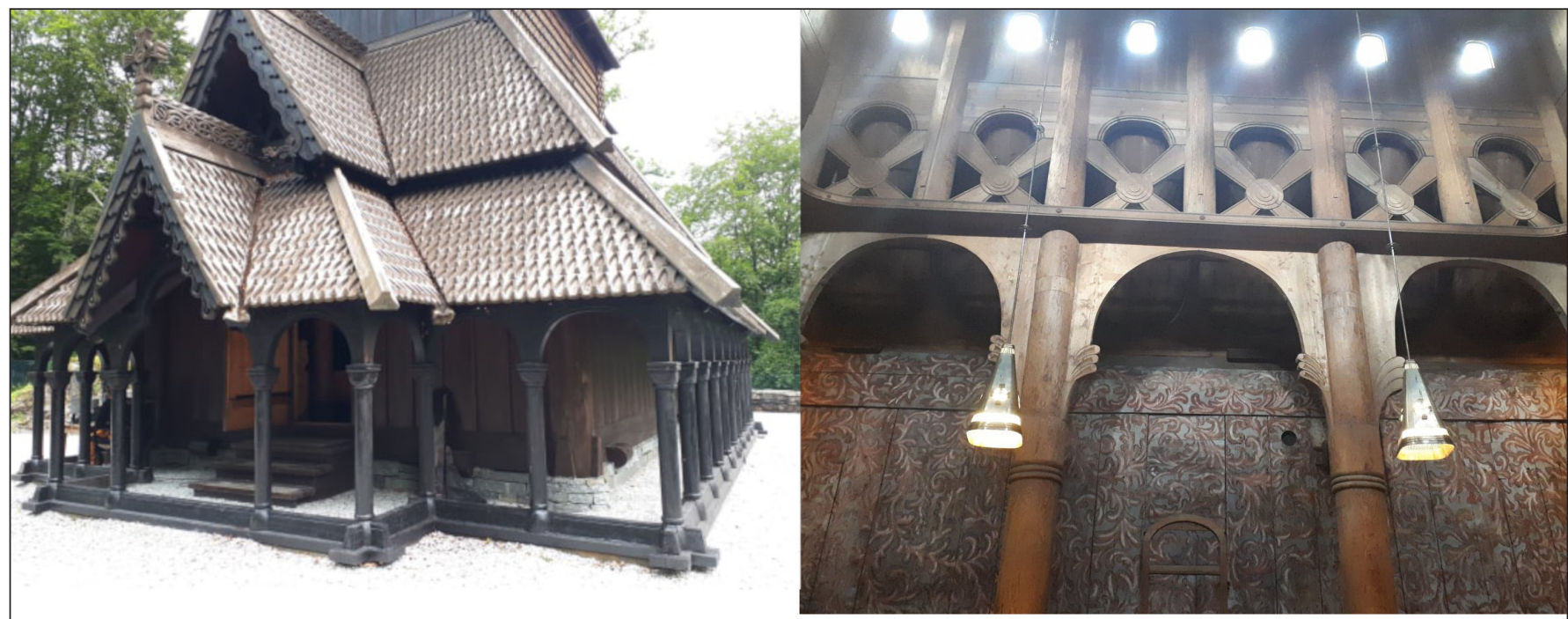

1

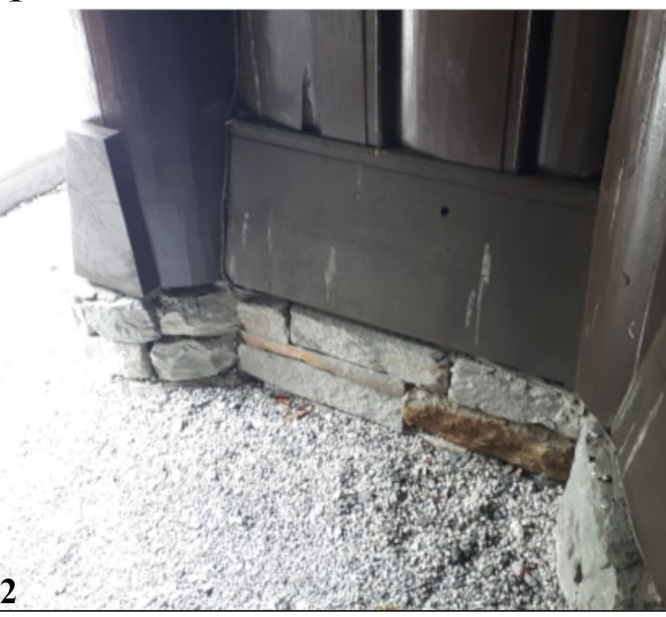

3

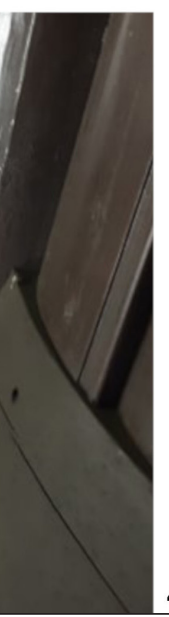

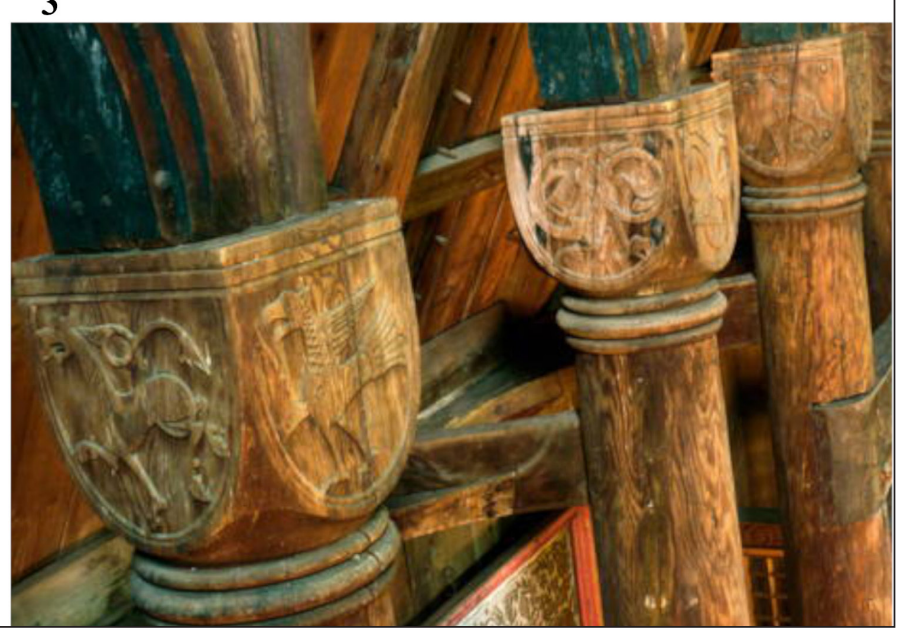

6. kép. Néhány példa a köalapozásra, az oszlopdíszitésekre és a Szent András keresztre. 1-2. Fantoft (fotó: Szilágyi Kata), 3. Heddal (fotó: Szilágyi Kata), 4. Urnes (fotó: @ OUR PLACE The World Heritage Collection, forrás: Unesco, 
szerü héjat formálva. A galéria építészeti előnye az volt, hogy egyrészt megvédte a templomot az időjárástól és bonyolult tetőszerkezet kialakítását tette lehetővé, másrészt a galériát közösségi találkozóhelyként is használták a szertartás előtt és után. Az alapszerkezet középső részén gerendákat illesztettek be a falakat lezáró vízszintes gerendával azonos magasságban (BJERKNES \& LidÉN 1975, 55-90; JENSENIUs 1988, 11, 19, 23-25). Az alapszerkezetben ezen gerendák felett néhány esetben Szent András keresztjét használták keresztrúdként; ebben az esetben az alapkeret legfelső része az oszlopok felett kívülről nyitott lenne, ennek elkerülése végett az alsó falakhoz hasonlóan lécekkel fedték be ezt a részt is (CHRISTIE 1981, 228; HoHLER 1981, 264; VALEBRokK 1993) (5-6. kép).

\section{TETŐ}

Az egyhajós templomokra egyszerủ nyeregtető, míg a bonyolultabb templomokra meredek tető jellemző, amelyek több szintből és tetőlépcsőből állnak, ezáltal alakítva ki a dongatemplomok ikonikus (északi) stílusát. A tetőszerkezet elemeinek fokozatos csökkenése miatt az épületek nagyobbaknak tünnek, mint amilyenek valójában, ezt a kialakítást „kényszerített perspektíva technikának” nevezik (ANKER 1997, 190-195). A 19. században Lorentz Dietrichson összehasonlította ezt a típusú tetőszerkezetet más jelentős norvég faépítménnyekkel, így a viking hajókkal is (ANKER 1997, 184-185). Feltételezése alapján a korabeli hajóépí-
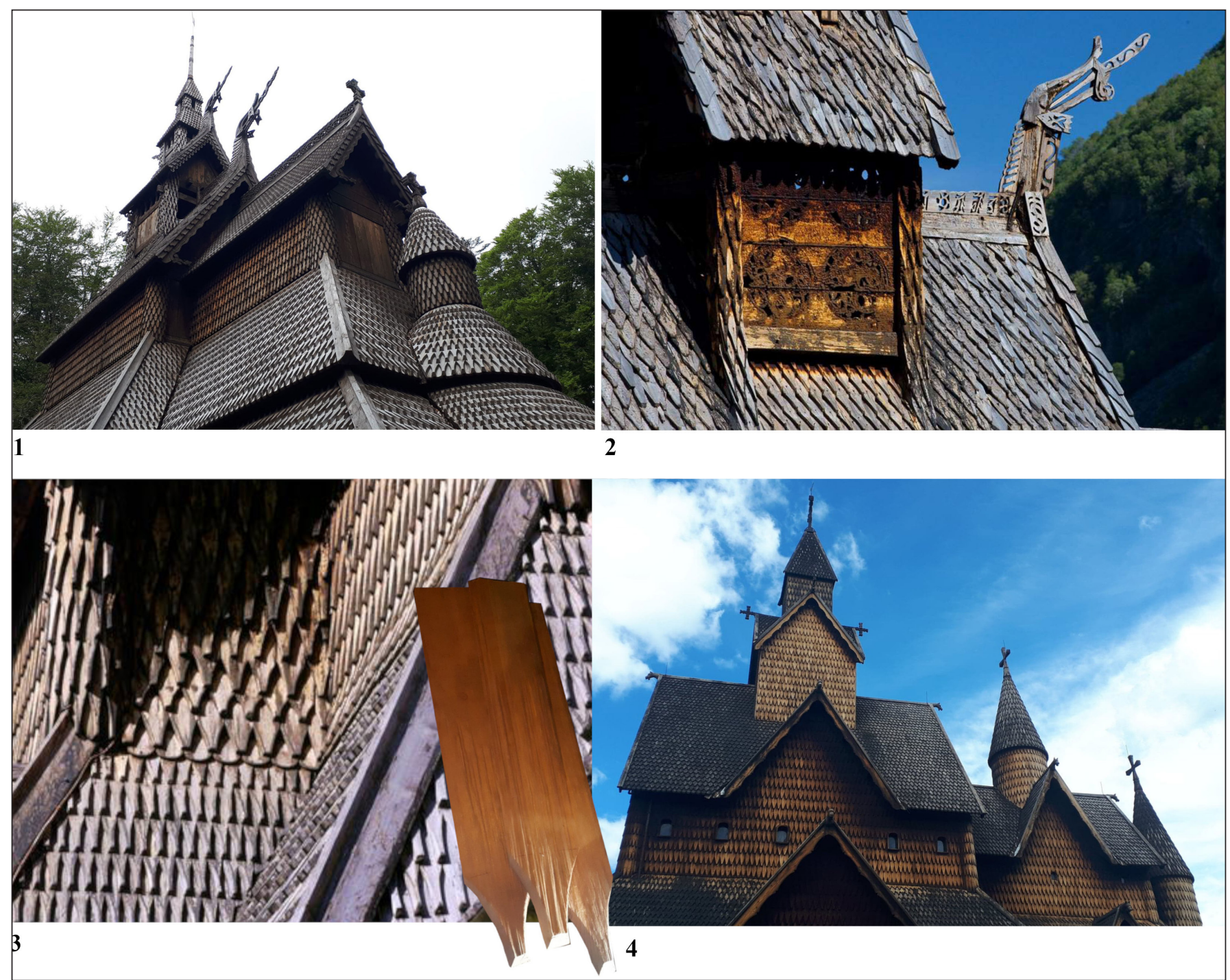

7. kép. Tetözsindely, az északi és a keresztény vallás díszitő motívumai az oromzaton 1. Fantoft (fotó: Szilágyi Kata), 2. Borgund (forrás: www.visitnorway.com), 3. Urnes (fotó: @ OUR PLACE The World Heritage Collection, forrás: Unesco, https://whc.unesco.org/en/documents/130610), 4. Heddal (fotó: Szilágyi Kata) 
tés állandó szempontjait alkalmazták a dongatemplomok esetében is. Ez az elmélet azonban vitatott, ugyanis napjainkban néhány szakértő (pl. AHRENs 2001) hasonlóságot vél felfedezni a dongatemplomok fedése és más kortárs nyugat-európai tetőszerkezetek között, mint pl. a svédországi Löjstában a szárazfalazású Gardatemplom, több dán viking kori épület, pl. a kör alakú erődítmény Fyrkatban, Jelling és Framlev történelmi városok templomai, az izlandi Hólar-székesegyházból származó Flatatunga táblák, valamint a németországi 8-11. századi kereskedelmi település, Hedeby (Haithabu) épületei (HaUglid 1970, 117-144) (7. kép).

\section{DÍSZÍTŐELEMEK ÉS KAPUK}

A gazdag faragványokon látható istenségek, személyek és tárgyak az északi mitológiából eredeztethetők. A faragványok egy része védekező varázslatként, apotropaikus, vagyis bajelhárító, rontás elleni védőelemként müködhetett, ezeket gyakran a nyeregtetők szélein helyezték el. További rendszeresen előforduló faragott elemnek tekinthető a kereszt- és sárkányábrázolás, különösen a stilizált sárkányfejek, de felbukkannak más kígyók és szörnyek is. A kereszteket valószínüleg inkább a természeti szellemekkel szembeni hatékony védekezésnek, mintsem az új vallás szimbólumának szánták (ANKER 1997, 265-267). A stilizált sárkányfejek többnyire kelet-nyugati irányban helyezkedtek el a tetőn, a Nap mozgásának megfelelően. Ennek oka vélhetően az lehetett, hogy a sárkány démonnak számított, amelyet csak a saját képe tudott megszelídíteni. Azonos típusú sárkányfejek voltak fellelhetők a viking hajókon is, itt azonban mágikus szereppel rendelkeztek, a hajót a sárkány erejével ruházták fel.

Hasonló faragványok a dongatemplomok egyéb részein is előfordulnak. Egy jól ismert példa a heddali püspöki szék, amin egy jelenetet látható Sigurd, a sárkányölő történetéből, amely vélhetően a pogány mesék és a keresztény tanítások között teremtett kapcsolatot. A dongatemplomok díszítése leginkább a mintegy 120 megmaradt kapuról ismert, amelyek többsége mára elpusztult templomok maradványa (ANKER 1997,

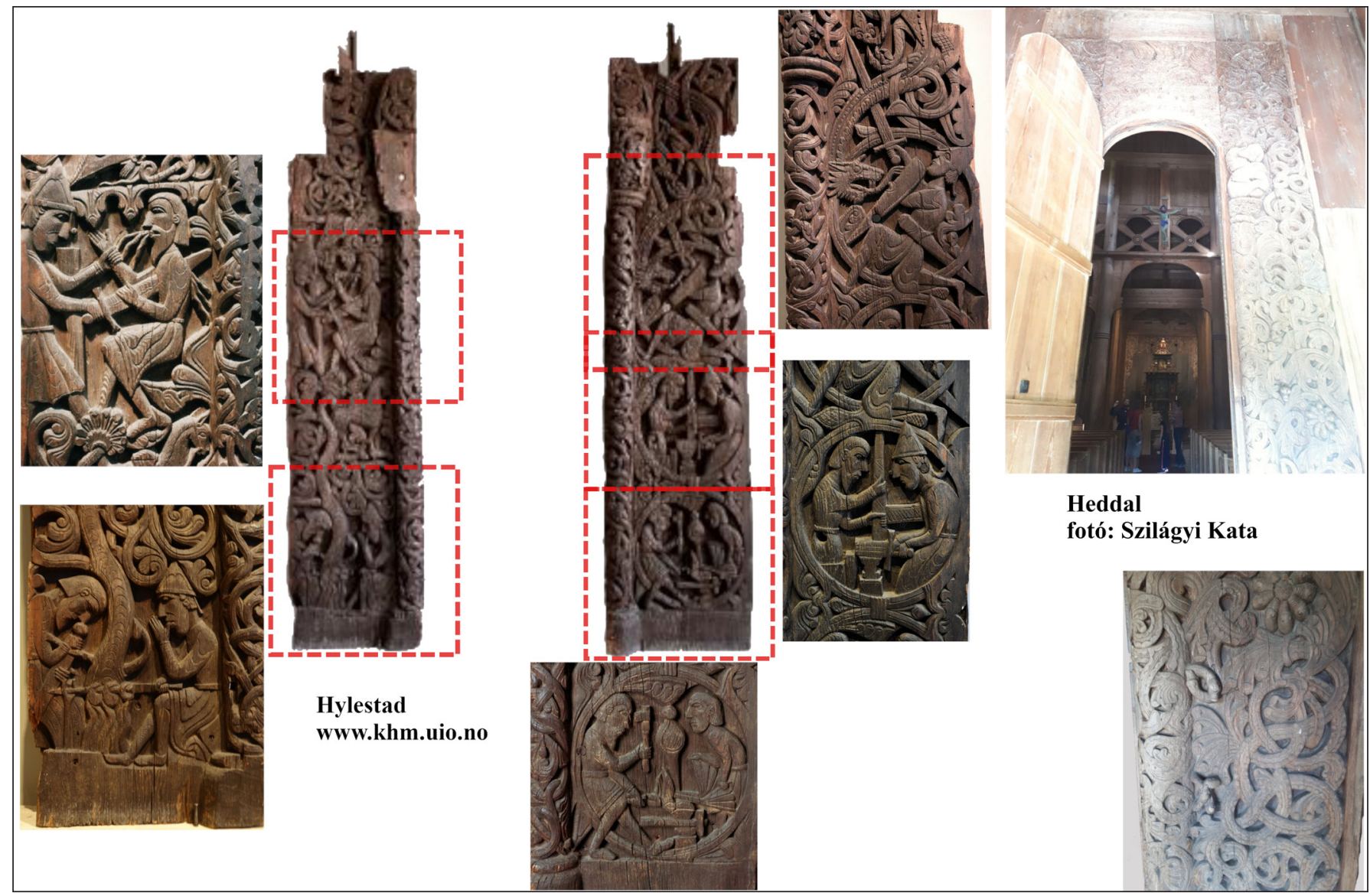

8. kép. Hylestad és Heddal dongatemplomokból származó kapuk (fotó: Hylestad@ University of Oslo, fényképész: Ove Holst, forrás: Universitetet i Oslo, Kulturhistorisk Museum, https://www.khm.uio.no/) 
225). Ilyen például a hylestadi dongatemplom /ID: C4321/ (ANKER 1997, 253-256; Universitetsmuseet 2020), amely a 12. század második felében épült és 1838-ban semmisült meg. Jelenleg a kapu az oslói Kultúrtörténeti Múzeumban látható (8. kép), és a heddali püspöki székhez hasonlóan Sigurd történetének jeleneteit örökíti meg. A kapuk magas szintű müvészeti minősége és kitünő kivitelezése rendkívüli szakértelmet és munkát követelt meg. Az alkotások többsége a liminalitás (határhelyzeti állapot) koncepciójával jellemezhető, ami a küszöb átlépésének metaforájával állhat összefüggésben. A küszöb átlépésének aktusa a menny fogalomkörével is kapcsolatba hozható: a templomba belépés mozzanata során a „hétköznapi” világból átlépünk egy „szent” helyre (FALKENBURG 2019, 20-24).

\section{KÉZMÜVES MESTEREK}

A dongatemplomok építési technikájának ismeretét vándorló kézműves mesterek terjesztették el a különböző régiókban. Ebben a folyamatban a kézmüves mester, a szakképzett ács kulcsfontosságú személy lehetett, mivel a dongatemplomok kivitelezését és a népi építészeti hagyományok érvényre juttatását mindig az adott régió helyi adottságai és az elérhető építőanyagok fényében kellett megoldaniuk. A mesternek megfelelő megoldást kellett találnia, hogyan tudja a helyi környezeti feltételeket érvényesíteni és összekapcsolni a templom gyakorlati igényeivel és vallási szerepével, és ehhez figyelembe kellett vennie a domborzatot, az éghajlatot, a nyersanyagokat, a helyi hagyományok és építészeti szokások esztétikáját is. Ennek eredményeként mind a mester egyedi, különleges „kézjegye”, mind a helyi közösség (amely lehetett vallási, politikai vagy más, kisebb társadalmi csoport) kollektív kulturális emlékezete erősen befolyásolta a templom arculatát. Az építőmester „kézjegye”, egyedi megoldásai néha lehetővé teszik a dongatemplomok mögött rejlő személy azonosítását. Nagyon sok hasonlóság fedezhető fel például Gol, Hegge és Borgund fatemplomai között (ANKER 1997, 139), ami azt jelezheti, hogy ezeknek a dongatemplomoknak az építését ugyanaz a mesterember irányíthatta (ANKER 1997).

Az építőmesterek vezetői lehettek (építő)munkások egyfajta társulásának, beleértve a szakképzetlen fizikai segítőket is. Az utóbbiak közül többeket valószínüleg helyben foglalkoztattak, míg a szakképzett személyek egyénileg vagy ács-csoportokban utazhattak, egy egylet vagy valamilyen kézmüves szervezet tagjaiként (HAUGLAND \& DoLVEN 2021). Az utazással egybekötött tudástranszfer kétféle módon történhetett: a norvég szakemberek más területeken zajló építkezéseket kerestek fel és az ott tapasztaltakat, az új ötleteket és tudást hazavitték, vagy a mai Norvégia területén idegen mestereket alkalmaztak, és ezáltal importálták külföldről az építészeti gyakorlatot és stílust. A 12. és 13. század folyamán fontos hagyomány volt, hogy a kézmüvesek (mesterek és tanoncok) és kereskedők egyletekbe szerveződtek, amelyek a középkor végére számottevő gazdasági és politikai hatalommal bírtak Észak-Európában. A kézmüves mesterek fontos szerepet játszottak a kollektív kulturális emlékezet megőrzésében és közvetítésében a dongatemplomok építészeti megoldásain keresztül (Assmann 2008, 110-112).

\section{AZ EMLÉKEZET JELENTŐSÉGE}

A fatemplomok megjelenésének tervezésében - a mesterek egyéni stílusa mellett - számos térbeli és társadalmi adottságot is figyelembe kellett venni, úgymint a helyi domborzat, a víz közelsége, a közösség lélekszáma és a helyi lakosság domináns vallása. Egy különleges hely kiválasztása templom építésére közvetlen kapcsolatot jelenthetett az ősökkel, a földdel, a helyi tájjal, máskor csupán azzal volt magyarázható, hogy védett, kiemelkedő, jól látható és kedvező építési adottságokat jelentő hely volt. Ezek az aspektusok a megfelelő nyersanyagok kiválasztásában, pl. a faanyag származási helyében is megnyilvánulhattak. A faanyagot gyakran évekkel az építkezés megkezdése előtt elő kellett készíteni, mivel az előkészítéshez hozzátartozott a faágak levágása, visszametszése, majd ezután a fát hagyták „kivérezni”. Ilyenkor a fa a törzsben lévő gyantát visszavonja a sejtjeibe, így a faanyagot ellenállóvá teszi a rothadással szemben, így keletkezik az ún. szívfa. Ezt a speciális fenyőfa típust „ércfenyőnek” is nevezik, és különösen értékesnek számított az északi világban (FALKENBURG 2019, 11). A templomépítés ezen jellegzetességei a helyi közösségek kollektív kulturális emlékezetében is tükröződhettek. 


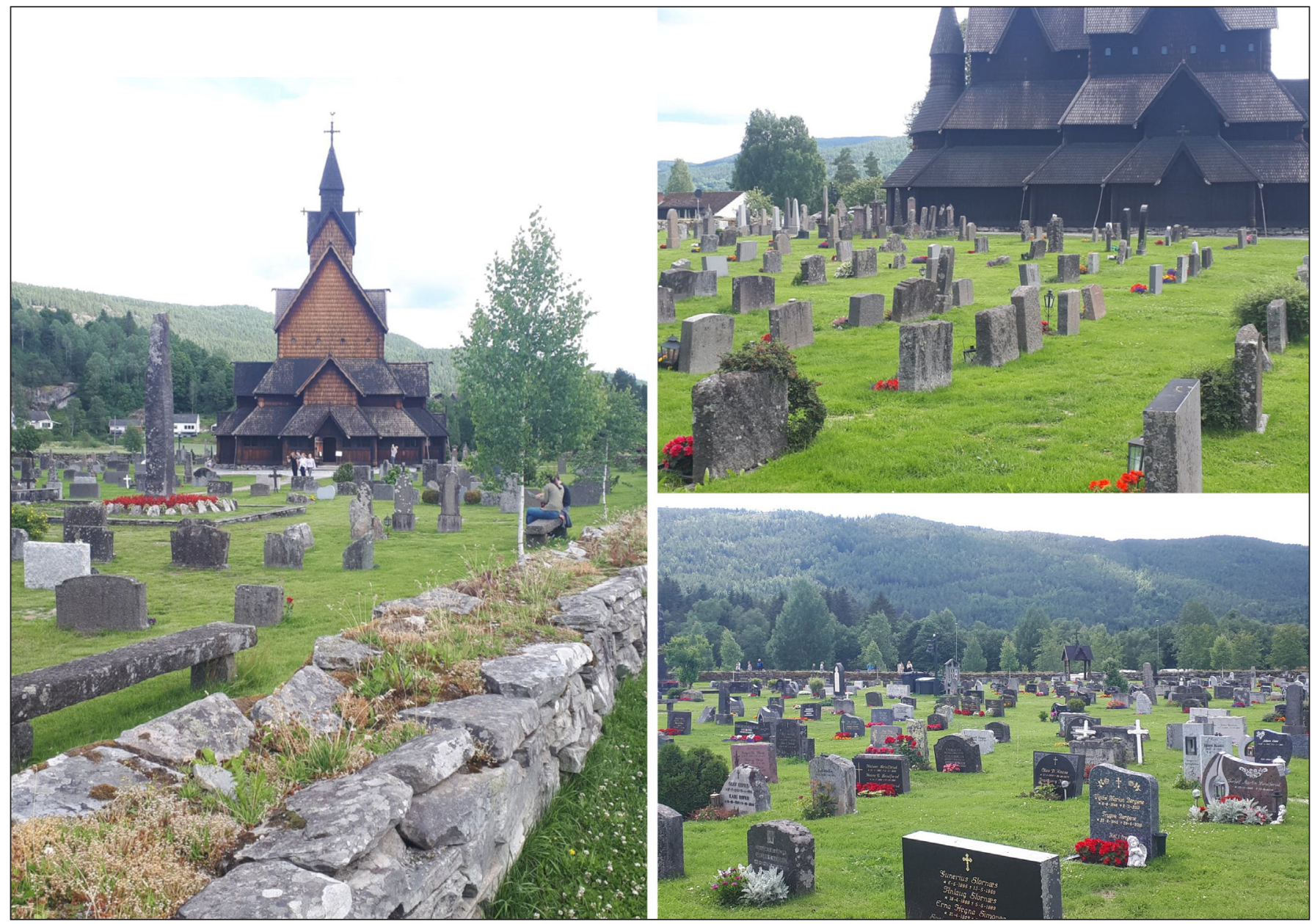

9. kép. A mai aktívan használt temető a heddali fatemplom körül (fotó: Szilágyi Kata)

A templom a közösség gyülekezőhelye volt, ahol a vallás gyakorlása és az ismétlődő rituális tevékenységek adták az épület sajátos jelentéskészletét. Ennek példájaként említhetjük a temetési szertartást, amely folyamatosan formálódott a templom körüli térben. Később a templom környezetét a temetkezés állandó helyeként határozták meg és szabályozták az egyházi hatóságok, így a temetkezés tartós köteléket teremtett és teremt ma is a közösség és az adott táj között. Közel 800 év után Urnesben és Heddalban még ma is a fatemplomokat használják a temetési szertartás helyszíneként, és közvetlen környezetüket temetkezési helyként. A heddali az összes megmaradt dongatemplom közül a legnagyobb, napjainkban is müködő plébániatemplom, amely szertartások, keresztelések, konfirmációk, esküvők és temetések helyszíne (9. kép).

Napjainkban a dongatemplomok a kereszténység alapvető eszmei üzenetét és az egyetemesség igényét jelképező épületekké váltak. Egyedi építészetük és különleges környezetük látványossá teszi őket, így közvetítő szerepet láthatnak el a kulturális emlékek megörzésében és megjelenítésében. Egy vallási épület megtervezésének fontos eleme a templomról alkotott határozott elképzelés kialakítása, amely ezt követően építészeti formaként megvalósulhat (AssmANN 2008, 109-113). Ebben a kognitív folyamatban az egyik kulcsszereplő a kézmüves mester, aki képes volt ötvözni a helyi adottságokat a népi építészeti hagyományokkal. Ebben az értelemben a dongatemplomok egyszerre egy építészeti hagyomány és egy kozmológiai koncepció megnyilvánulásai; olyan faépületek, amelyek vizuális nyelve és kulturális öröksége egyszerre egyedi és egyetemes.

\section{KÖSZÖNETNYILVÁNÍTÁS}

Köszönjük a Magyar Régészet folyóirat szerkesztőinek, különösen Dr. Laszlovszky Józsefnek, hogy értékes megjegyzéseikkel látták el a kéziratot. Szilágyi Kata norvégiai tartózkodása és ősrégészeti témájú kutatása a Magyar Állami Eötvös Ösztöndíj „Nyersanyag és információáramlás társadalomrégészeti szempontú 
Szilágyi Kata-Anette Sand-Eriksen • A középkori norvég fatemplomok: épitett örökség és az emlékezet helyei

kutatása Közép és Észak-Európa területén a Kr.e. 7-3. évezredben” (MAEÖ 2020-2021/159019) címü posztdoktori ösztöndíjának segítségével valósult meg.

BiBLIOGRÁFIA

Ahrens, C. (1982). Frühe Holzkirchen im Nördlichen Europa. Hamburg: Helms Museum.

Ahrens, C. (2001). Die frühen Holzkirchen Europas. Stuttgart: Theiss.

Anker, L. (2005). The Norwegian Stave Churches. Oslo: ARFO.

Anker, P. (1997). Stavkirkene: deres egenart og historie [A fatemplomok: jellemzőik és történetük]. Oslo: Cappelen.

Assmann, J. (2008). Communicative and Cultural Memory. In A. Erll \& A. Nünning (eds.), Cultural Memory Studies. An International and Interdisciplinary Handbook (pp. 109-118). Berlin, New York: Gruyter.

Bampi, M., Buzzoni, M., Haugen, O.E., Meregalli, A. \& Panieri, L. (2018). Le lingue nordiche nel medioevo. Vol. 1: Testi. Oslo: Novus Press.

Berend, N., Laszlovszky, J. \& Szakács, B. Zs. (2007). The kingdom of Hungary. In N. Berend (ed.), Christianization and the Rise of Christian Monarchy: Scandinavia, Central Europe and Rus' c. 900-120 (pp. 319-368). Cambridge: Cambridge University Press.

Bjerknes, K. \& Lidén, H. E. (1975). The Stave Churches of Kaupanger. Oslo: Fabritius Forlag.

Christie, H. (1981). Stavkirkene - arkitektur [A fatemplomok: építészet]. In K. Berg (ed.) Norges Kunsthistorie 1: Fra Oseberg til Borgund (pp. 139-252). Oslo: Gyldendal Norsk Forlag.

Falkenburg, J. (2019). Looking Through Portals. An investigation of stave church portals as display objects in Norwegian museums. Oslo: University of Oslo.

Flintoe, J. (1834). Samlinger til det Norske Folks Sprog og Historie [Gyüjtemény a norvég nép nyelvéhez és történetéhez]. Christiania.

Haugland, H. \& Dolven, A. S. (2021). Laug i Europa [Egyletek Európában]. In E. Bolstad (ed.), Store Norske Lexikon._https://snl.no/laug_Letöltés: 2021.02.25.

Hauglid, R. (1970). Norwegische Stabkirchen. Oslo: Dreyer.

Hoftun, O. (2008). Kristningsprosessens og herskermaktens ikonografi i nordisk middelalder [A keresztelés és az uralkodói hatalom ikonográfiája az északi országokban a középkorban]. Oslo: Solum.

Hohler, E. B. (1981). Stavkirkene. Den dekorative skurd [Fatemplomok. A díszítő faragványok]. In K. Berg (ed.) Norges Kunsthistorie 1: Fra Oseberg til Borgund (pp. 253-355). Oslo: Gyldendal Norsk Forlag.

Jensenius, J. H. (1988). Lomen Stavkirke: en matematisk analyse [A lomeni fatemplom: matematikai elemzés]. Riksantikvarens Skrifter Nr. 5. Oslo: Avheim \& Eide. 
Szilágyi Kata-Anette Sand-Eriksen • A középkori norvég fatemplomok: épitett örökség és az emlékezet helyei

Jensenius, J. H. (2000). Research in Medieval, Norwegian Wooden Churches. Relevance of Available Sources. Nordic Journal of Architectural Research 13 (4), 7-23.

Jensenius, J. H. (2017). Stavkirke Info [Információ a fatemplomokról]. https://stavkirke.info/_Letöltés: 2020.10.27.

Stavkyrkjeeigarforum (2020). Stavkyrkjene - Noreg sitt bidrag til verdsarkitekturen [A fatemplomok: Norvégia hozzájárulása a világ építészetéhez]._https://stavechurch.com Letöltés: 2020.10.27.

Tschudi-Madsen, S. (2019). Stavkirke [Fatemplom]. In E. Bolstad (ed.), Store Norske Lexikon. https://snl. no/stavkirke_Letöltés: 2020.10.27.

Universitetsmuseet (2020). Universitetsmuseenes IT-organisasjon MUSIT. https://unimus.no Letöltés: 2020.11.19.

Valebrokk, E. (1993). Norwegische Stabkirchen: Architektur, Geschichte und Traditionen. Oslo: Boksenteret.

Wikipedia (2020). Vang Stave Church. https://en.wikipedia.org/wiki/Vang_Stave_Church_Letöltés: 2020.12.20. 